\title{
A TEORIA DA DEFERÊNCIA E A PRÁTICA JUDICIAL: UM ESTUDO EMPÍRICO SOBRE O CONTROLE DO TJRJ À AGENERSA
}

\author{
EDUARDO JORDÃO ${ }^{1}$ \\ RENATO TOLEDO CABRAL JUNIOR ${ }^{2}$
}

RESUMO: Este artigo é produto de pesquisa desenvolvida por alunos da Escola de Direito do Rio de Janeiro da Fundação Getulio Vargas durante o segundo semestre do ano de 2017. O objetivo central do trabalho foi verificar o nível de deferência do Tribunal de Justiça do Estado do Rio de Janeiro (TJRJ) às decisões proferidas pela Agência Reguladora de Energia e Saneamento Básico do Estado do Rio de Janeiro (AGENERSA). Foram adotados três parâmetros distintos: (i) a deferência pelo discurso; (ii) a deferência pelo resultado; e (iii) a deferência pela amplitude de controle. Ao final, tais variáveis foram conjugadas para indicar possíveis tendências do TJRJ no controle judicial da AGENERSA.

Palavras-Chave: Agências reguladoras; Controle judicial; Teoria da deferência; Deferência judicial.

1 Professor da FGV Direito Rio. Doutor em Direito Público pelas Universidades de Paris (Panthéon-Sorbonne) e de Roma (Sapienza), em cotutela. Master of Laws (LL.M) pela London School of Economics and Political Science (LSE).

2 Mestrando em Direito Público na Universidade do Estado do Rio de Janeiro (UERJ). Assistente de pesquisa na FGV Direito Rio. 


\section{DEFERENCE AND JUDICIAL PRACTICE: AN EMPIRICAL STUDY OF THE JUDICIAL REVIEW OF AGENERSA}

ABStRAct: This article is a research product developed by students of Fundação Getulio Vargas (FGV) Law School in Rio de Janeiro during the second semester of 2017. The main goal of the study was to verify the level of judicial deference of the Court of Justice of the State of Rio de Janeiro (TJRJ) to the decisions taken by AGENERSA, the Independent Regulatory Commission of Energy and Basic Sanitation of the same state. Three different parameters were used: (i) the deference by the discourse; (ii) the deference by the result; and (iii) the deference by the extent of the review. These variables were conjugated to evaluate some trends of the Court in reviewing the decisions of regulatory agencies.

KEYWORDS: Regulatory agencies; Judicial review; Deference doctrine; Judicial deference. 


\section{A TEORIA DA DEFERÊNCIA E A PRÁTICA JUDICIAL: UM ESTUDO EMPÍRICO SOBRE O CONTROLE DO TJRJ À AGENERSA}

\section{INTRODUÇÃO}

Este artigo é produto de pesquisa desenvolvida por alunos da Escola de Direito do Rio de Janeiro da Fundação Getúlio Vargas (FGV Direito Rio) na disciplina de atividade complementar obrigatória denominada "Oficina de Pesquisa", realizada durante o segundo semestre do ano de $2017^{3}$. O objetivo central do trabalho foi verificar o grau de deferência do Tribunal de Justiça do Estado do Rio de Janeiro (TJRJ) às decisões proferidas pela Agência Reguladora de Energia e Saneamento Básico do Estado do Rio de Janeiro (AGENERSA).

Para este fim, foram lidas e examinadas mais de uma centena de decisões, classificadas posteriormente em função de três parâmetros distintos: (i) a deferência pelo discurso, com a verificação da eventual existência, nas decisões analisadas, de um discurso de deferência em favor da agência reguladora; (ii) a deferência pelo resultado, com a verificação do resultado final do processo, mantendo ou revisando a decisão da agência; e (iii) a deferência pela amplitude de controle, com a verificação da extensão do controle operado pelo tribunal, se limitado aos aspectos formais da decisão administrativa controlada ou exercido também sobre os seus aspectos substantivos. Ao final, tais variáveis foram conjugadas para indicar possíveis tendências do TJRJ no controle judicial da AGENERSA.

A crise do Estado do bem-estar social resultou num período de intensa reforma administrativa nas últimas décadas do século XX. Antes considerado o principal agente da economia (sobretudo em seu modo de intervenção direta por meio de empresas estatais), o Estado teve seu papel reconfigurado em um contexto de sucessivas privatizações e desestatizações. O processo foi acompanhado de uma necessidade cada vez maior de fiscalizacão das atividades que foram delegadas ao setor privado. Este movimento levou ao que se convencionou chamar de Estado regulador (MAJONE, 1999) 4 .

3 A catalogação das pesquisas e a apresentação do trabalho final apresentado à Faculdade foi fruto do trabalho feito pelos alunos Alexandre Blois, Eduardo Adami, Fábio Rodrigues, Gabriel Arlé, Giulia Costa, Julia Rezende, Luiza Brumati, Maria Eduarda Gomes e Rodrigo Roll sob a orientação do assistente de pesquisa Renato Toledo Cabral Iunior e supervisão do professor Eduardo Tordão.

4 Marcal Iusten Filho (2011, p. 655) identifica quatro distincões significativas entre essa nova concepcão estatal diante do Estado de Providência: (i) a transferência para a iniciativa privada de atividades anteriormente desenvolvidas pelo Estado, inclusive com a liberalização de atividades até então monopolizadas; (ii) a preferência pelo 


\section{REVISTA ESTUDOS INSTITUCIONAIS}

A liberalizacão de alguns setores da economia à iniciativa privada constituiu um processo extremamente complexo e sensível. Para capitaneá-lo, foi frequente em vários países a opcão pela criacão das chamadas aqências requladoras - entidades relativamente independentes da administracão central, com autonomia reforcada (ARAGÂO, 2002), compostas por especialistas na matéria, com garantias de poder decisório insulado do processo político e dotadas de significativos recursos financeiros e humanos. Com esse modelo, a requlacão de atividades econômicas antes submetidas ao monopólio estatal (como os servicos de telecomunicacões, energia elétrica, gás, transporte ferroviário, etc.) passou a ser atribuída a uma instituição pública cuidadosamente desenhada para lidar com a complexidade dessas funcões (KING, 2008, p. 409). No Brasil, esse fenômeno foi constatado sobretudo no final da década de 1990 e no início da década seguinte 5 .

A proliferação destas entidades administrativas especializadas gerou alguns desafios para a teoria do direito administrativo. Naquilo que concerne mais especificamente a este artigo, questionou-se que tipo de controles deveriam ser aplicados a elas, e se eles deveriam diferir daqueles que se aplicavam às autoridades administrativas tradicionais.

instrumento interventivo indireto, por meio da regulacão da atividades sociais e econômicas (competência regulatória); (iii) a atuação estatal norteada não apenas pelas correç̃es das falhas de mercado, mas também admitindo-se a possibilidade de intervenção destinada a propiciar a realização de certos valores de natureza política e social; bem como (iv) a institucionalização de mecanismos de disciplina permanente das atividades reguladas.

5 Confira-se, a propósito, o relato de Gustavo Binenbojm (2014, p. 266-267) sobre o assunto: "Com efeito, a superação da crise econômico-gerencial do Estado brasileiro, cujo auge se atingiu na década de 1980, passava pela reformulação das estratégias de intervenção do Estado na economia. Através de desestatizações, privatizações e flexibilização de monopólios, o modelo de Estado empresário, calcado em forte intervenção direta na economia, foi substituído, a partir dos anos 1990, pelo modelo de Estado regulador, cuja intervenção opera-se de modo indireto. O sucesso da aludida conversão dependia, contudo, de maciça atração do capital privado, e, para tanto, fazia-se imprescindível superar a histórica crise de credibilidade do país e de suas instituições. Ou seja: era preciso vender o Brasil como um bom negócio, garantindo aos investidores a manutenção dos contratos celebrados e o direito de propriedade. Nisso reside, fundamentalmente, a razão da escolha pelo modelo de agências reguladoras: entidades com grau reforçado de autonomia, investidas de funções técnicas e, sobretudo, imunizadas das ingerências político-partidárias. Por outro lado, a transferência de serviços públicos e/ou de sua execução à iniciativa privada não poderia conduzir a um Estado puramente liberal, guiado pelo não-intervencionismo. Daí as agências constituírem também efeito da reforma por que passou o Estado brasileiro, na medida em que foram institucionalmente incumbidas da regulação tanto de serviços públicos desestatizados, como de outras atividades econômicas de relevante interesse social, devolvidas total ou parcialmente à iniciativa privada". 


\section{A TEORIA DA DEFERÊNCIA E A PRÁTICA JUDICIAL: UM ESTUDO EMPÍRICO SOBRE O CONTROLE DO TJRJ À AGENERSA}

Em diversos países, ganhou relevo a discussão a propósito da conveniência da aplicação de alguma deferência (ou autocontenção) do controlador às decisões tomadas por estas entidades, em função das suas características.

A "teoria da deferência" corresponde à tese segundo a qual a autocontenção seria conveniente (VERÍSSIMO, 2012). No caso específico do controle judicial, o argumento em favor da deferência seria o seguinte. Como a matéria regulatória é tecnicamente complexa, a deferência judicial às decisões das agências reguladoras transmitiria a ideia de respeito judicial a uma instituição comparativamente mais bem adaptada para enfrentá-la (tanto em função da natureza da sua atuação diuturna, como em função do seu maior aparelhamento institucional). Além disso, veicularia a intenção de não prejudicar a coerência e a dinâmica da política regulatória da autoridade administrativa. Dito de outro modo, a justificativa do controle judicial deferente às decisões das agências reguladoras reside, de um lado, na inadequação subjetiva e objetiva dos tribunais para a regulação; de outro, no prejuízo que a sua intervenção pode causar à política regulatória das agências. ${ }^{6}$

Sob um certo ângulo, a aplicação de um controle judicial deferente sobre decisões das agências reguladoras veicula a compreensão de que matérias tecnicamente complexas devem ser definidas prioritariamente pelas autoridades administrativas especializadas - aos tribunais caberia apenas uma revisão relativamente superficial.

A realização de estudos empíricos para verificar (e medir) a adoção judicial da teoria da deferência tem relevância acentuada na literatura jurídica. Nos Estados Unidos, por exemplo, William Eskridge e Lauren Baer (2008) realizaram importante pesquisa em que questionam a importância prática da doutrina Chevron e a sua percepção como marco do direito administrativo americano. Os autores consultaram todas as 1.014 decisões da Suprema Corte americana entre 1984 (ano da decisão paradigmática) e 2005 que envolviam o controle judicial de interpretação legislativa promovida por uma autoridade administrativa. Chegaram à conclusão de que o regime de Chevron só era mencionado em $8,3 \%$ delas. Em mais da metade dos casos, nenhum precedente sobre deferência judicial sequer foi citado. A despeito disso, o estudo indicou uma propensão à manutenção da interpretação da autoridade administrativa. Outras pesquisas empíricas, também nos Estados Unidos, demonstraram o aumento percentual relevante de decisões em favor das agências nos tribunais inferiores nos anos que se seguiram a Chevron ${ }^{7}$.

\footnotetext{
${ }^{6}$ Para desenvolvimento destes argumentos e ilustrações práticas e jurisprudenciais de seu uso, ver o capítulo 1.1 de Jordão (2016).

${ }^{7}$ Confira-se, por exemplo, Kerr (1998) e Schuck e Elliot (1991). Kent Barnett e Christofer Walker (2017, p. 01-73) demonstraram que, nas cortes federais de apelação, a aplicação da doutrina Chevron pelos tribunais garantiu uma taxa de êxito $25 \%$ superior em favor das agências americanas
} 


\section{REVISTA ESTUDOS INSTITUCIONAIS}

No Brasil, alguns estudos sobre o tema vêm sendo desenvolvidos, com enfoque sobretudo nas agências reguladoras federais ${ }^{8}$. Uma pesquisa do CNJ, por exemplo, analisou 1.371 ações judiciais em que foram questionadas decisões de agências reguladoras entre 1994 e 2010 e revelou que mais de $80 \%$ dos casos que tiveram seu mérito julgado pelos tribunais superiores foram favoráveis às agências - embora, no decorrer do processo, a incidência de decisões desfavoráveis esteja presente com alguma incidência (AZEVEDO; FERRAZ JUNIOR; MARANHÃO, 2011). Segund o o relatório, a complexidade e o caráter estritamente técnicos das entidades administrativas autônomas é uma de suas razões de decidir. Juliano Maranhão (2016, p. 26-46), ao analisar o estudo, observa que (i) há uma supervalorização de questões procedimentais; (ii) os magistrados geralmente carecem de conhecimento técnico para resolver as questões; (iii) a dicotomia entre o direito público e privado dificulta a compreensão judicial sobre assuntos regulatórios complexos; e (iv) há uma insensibilidade ao raciocínio regulatório que, muitas vezes, leva o Poder Judiciário a um formalismo jurídico. ${ }^{9}$

Esse tipo de estudo possui grande importância porque, a partir da orientação judicial identificada, é possível saber até que ponto o controle judicial é uma engrenagem relevante do processo regulatório. Ao operar o controle sobre decisões administrativas, os tribunais podem terminar por tomar diretamente decisão diversa ou limitar o leque de decisões que poderiam ser adotadas pela administração pública. Naturalmente, este risco é tanto maior quanto mais intenso for o controle aplicado. Os resultados da pesquisa empírica podem revelar, portanto, se o Poder Judiciário preserva a coerência e a dinâmica das políticas regulatórias setoriais.

Outro ponto relevante é a segurança jurídica, especialmente no Brasil. A Administração Pública no Brasil vive um momento de altíssima incerteza jurídica ${ }^{10}$, em que os agentes administrativos, os tribunais e os setores regulados atuam num ambiente bastante fluido, no qual o resultado concreto de uma ação judicial é muitas vezes imprevisível

\footnotetext{
${ }^{8}$ Nesse sentido, ver, por todos, Wang, Palma e Colombo (2010) e Maranhão (2016).

9 Em razão de tais conclusões, o autor sugere, diante da especificidade dos dados relacionados às decisões sobre agências reguladoras, a criação de varas especializadas dotadas de uma equipe de conselheiros técnicos (economistas e engenheiros, por exemplo) treinados para lidar com matérias econômicas e regulatórias (MARANHÂO, 2016).

10 Não somente em razão do controle judicial, mas também pela crescente atuação dos Tribunais de Contas.
} 


\section{A TEORIA DA DEFERÊNCIA E A PRÁTICA JUDICIAL: UM ESTUDO EMPÍRICO SOBRE O CONTROLE DO TJRJ À AGENERSA}

(JORDÃO, 2017, p. 357). ${ }^{11}$ Daí porque os dados estatísticos podem ser relevantes para apontar tendências específicas da jurisprudência e orientar a atuação dos agentes envolvidos.

A verificação empírica e a mensuração da deferência judicial, no entanto, envolvem dificuldades não negligenciáveis. Em primeiro lugar, porque a definição de uma postura intrusiva ou deferente requer a avaliação de variáveis complexas e multifacetadas. A intensidade do controle a ser aplicado a uma decisão administrativa concreta envolve uma série de considerações subjetivas e até mesmo políticas, tanto dos tribunais em si como dos demais atores envolvidos nesta decisão, cuja conversão em dados objetivos se revela uma tarefa tormentosa.

Em segundo lugar, porque não há, no direito brasileiro, uma orientação jurisprudencial clara sobre o assunto, a servir de baliza para a mensuração da postura deferencial. Embora alguns julgados apontem para a necessidade de uma postura autocontida dos tribunais em matérias originariamente atribuídas às agências, não é possível identificar no Brasil um caso paradigmático tal como a doutrina Chevron nos Estados Unidos ${ }^{12}$, que definiu a relação entre os tribunais e as autoridades administrativas, elucidando a distribuição de competências entre eles (SUNSTEIN, 1990, p. 2078-2079). Desta ausência de orientação jurisprudencial pátria clara, decorre uma atuação descoordenada entre diferentes tribunais e instâncias judiciais, levando casos similares a razões de decidir e resultados finais distintos. Alinhar tais dados em categorias específicas, sem um parâmetro uniforme de comparação, dificulta ainda mais o trabalho do pesquisador na análise dos julgados sobre o controle

11 De fato, nem sempre o controle da atuação administrativa é positivo. Em primeiro lugar, porque, assim como os controladores podem corrigir erros, eles podem também desfazer acertos. O controlador não é infalível. Em segundo lugar, porque, se a intensificação reduz a possibilidade de abusos de poder perpetrados pelo administrador público, por outro lado, ela aumenta a possibilidade de abusos cometidos pelo próprio controlador. Finalmente, em um cenário em que as determinações jurídicas são cada vez mais inexatas e abertas à interpretação, é irreal supor que há respostas corretas para cada questão que é levada ao controlador. Há espaço de liberdade em grande parte das decisões tomadas pelo administrador público. E, se é assim, há um risco que o controle veicule não a correção de decisões tomadas pela entidade controlada, mas mera substituição de suas escolhas pelo controlador.

12 A referência é a Chevron U.S.A Inc. versus Natural Resources Defensa Council, Inc., 467 U.S. 837 (1984), caso em que a Suprema Corte americana defendeu longamente a autorrestrição judicial nos casos de controle de interpretações promovidas pelas autoridades administrativas de ambiguidades na legislação a elas pertinente. No julgamento desse caso, a Suprema Corte americana afirmou que "os juízes não são especializados na matéria" da regulação ambiental, e sugeriu que a utilização, pelo legislador, de termos ambíguos equivaleria a uma delegação para as agências, "que estariam numa melhor posição" institucional para conciliar os interesses contrapostos na legislação pertinente. 


\section{REVISTA ESTUDOS INSTITUCIONAIS}

judicial das agências reguladoras para que se possa chegar a uma conclusão senão definitiva, ao menos indiciária.

Em terceiro lugar, porque a junção da cultura de litigância das empresas brasileiras em determinados setores regulados, de um lado, e a precária estrutura do Poder Judiciário brasileiro, de outro, também compromete a análise. Afinal, o alto número de processos judiciais nos tribunais pátrios leva a uma produção massificada de decisões que, por questões pragmáticas, não são analisadas a fundo, levando a sentenças e acórdãos padronizados e genéricos.

Em quarto lugar, e por fim, porque o discurso da especialidade técnica das agências brasileiras pode ser comprometido pela realidade política nacional. Administrações em todos os níveis federativos, para garantir sua governabilidade, realizam coalizões que muitas vezes resultam na nomeação de dirigentes de agências reguladoras por razões eminentemente políticas, em prejuízo do modelo institucional teórico que motivou a criação das agências ${ }^{13}$ - e que fundamentaria a deferência judicial a elas.

A despeito destas dificuldades, parece-nos possível identificar variáveis que iluminam determinadas tendências específicas dos tribunais brasileiros em relação ao controle judicial das agências reguladoras. Neste artigo, a partir de dados jurisprudenciais em demandas envolvendo a Agência Reguladora de Energia e Saneamento Básico do Estado do Rio de Janeiro (AGENERSA), buscaremos avaliar questões como (i) se o Poder Judiciário do Rio de Janeiro adota um discurso de autorrestrição quando controla alguma decisão específica de uma agência reguladora (exame da deferência como discurso); (ii) se o percentual de revisão judicial é significativo (exame da deferência como resultado); e (iii) se o tribunal limita o objeto daquilo que pode revisar (exame da deferência como amplitude de controle).

A particularidade deste trabalho envolve não só a pesquisa e os parâmetros adotados ao longo da pesquisa, mas a própria escolha de uma agência reguladora estadual como objeto de exame. Com efeito, a doutrina costuma ter por enfoque as agências reguladoras federais ${ }^{14}$, tendo em vista sua importância na economia do país, o maior conhecimento geral sobre a sua existência e a presença de um maior número de entidades regulatórias independentes no Poder Executivo federal. A escolha de uma agência reguladora estadual, portanto, permite conhecer quais matérias são levadas ao Tribunal de Justiça local, quem

\footnotetext{
13 Sobre o tema, ver Jordão e Ribeiro (2017).

${ }^{14}$ Em relação à literatura sobre agências regionais e locais, ver Souza e Ribeiro (2013) e Oliveira (2010).
} 


\section{A TEORIA DA DEFERÊNCIA E A PRÁTICA JUDICIAL: UM ESTUDO EMPÍRICO SOBRE O CONTROLE DO TJRJ À AGENERSA}

são os litigantes no setor regulado e como o Poder Judiciário fluminense, que não possui câmaras especializadas em matéria de direito público, se comporta em relação ao contencioso regulatório do Estado.

Este artigo está estruturado da seguinte forma. Após esta introdução, a seção II abordará o objeto da pesquisa, a sua metodologia, os critérios de avaliação e uma síntese dos resultados obtidos. Na seção III, então, serão exibidos os dados empíricos a partir de classificação própria desenvolvida pelos autores, para que, ao final, tais variáveis possam ser conjugadas com o objetivo de identificar tendências de atuação do TJRJ. Na seção IV, por fim, serão apresentadas as conclusões finais do trabalho e breves reflexões sobre o assunto.

\section{MetOdologia dA PESQUISA E SÍNTESE DOS RESUltADOS}

Como já se afirmou acima, este artigo é produto de pesquisa desenvolvida por alunos da Escola de Direito do Rio de Janeiro da Fundação Getúlio Vargas (FGV Direito Rio) na disciplina de atividade complementar obrigatória denominada "Oficina de Pesquisa", realizada durante o segundo semestre do ano de 2017.

O objetivo inicial da pesquisa foi o exame da aplicação concreta da teoria da deferência judicial a todas as agências reguladoras no âmbito do Tribunal de Justiça do Estado do Rio de Janeiro (doravante, "TJRJ"). Em razão disso, foram catalogadas, de início, decisões judiciais em $2^{a}$ instância do TJRJ envolvendo as duas agências estaduais fluminenses: a Agência Reguladora de Energia e Saneamento Básico do Estado do Rio de Janeiro - AGENERSA e a Agência Reguladora de Serviços Públicos Concedidos de Transportes Aquaviários, Ferroviários e Metroviários e de Rodovias do Estado do Rio de Janeiro - AGETRANSP, desde o ano de 2005 (em que tais agências foram criadas) ${ }^{15}$ até agosto de 2017, data em que a pesquisa foi realizada pelos alunos da FGV Direito Rio.

$O$ projeto envolveu, em um momento inicial, a pesquisa dos termos "AGETRANSP" e "AGENERSA" na ferramenta de pesquisa de jurisprudência do TJRJ. Encontraram-se, então, 244 demandas em $2^{a}$

15 A AGENERSA é resultado do desmembramento, no ano de 2005, da antiga ASEP Agência Reguladora de Serviços Públicos Concedidos do Estado do Rio de Janeiro, originalmente criada pela Lei Estadual no ${ }^{2}$ 2.686/97. Conforme disposto no próprio site da agência: "No ano de 2005 é ocorreu a cisão da ASEP-RJ. O desmembramento da agência multisetorial aconteceu para dar mais agilidade ao processo regulatório. A ASEP-RJ foi extinta no dia 06 de junho de 2005, por força da Lei Estadual 4.555/2005 e sucedida pela Agência Reguladora de Serviços Públicos Concedidos de Transportes Aquaviários, Ferroviários e Metroviários e de Rodovias do Estado do Rio de Janeiro (AGETRANSP). Uma nova agência, a Agência Reguladora de Energia e Saneamento Básico do Estado do Rio de Janeiro (AGENERSA), foi criada em 06 de junho de 2005, através da Lei Estadual 4.556/05, publicada no Diário Oficial do Estado do Rio de Janeiro em 07 de junho de 2005, sob a forma de autarquia especial" (Disponível em: <https://bit.ly/2O8bQVG>. Acesso em: 24 out. 2018. 


\section{REVISTA ESTUDOS INSTITUCIONAIS}

instância com decisões finais sobre o assunto. Em seguida, adotou-se estratégia complementar e pesquisaram-se no site do TJRJ todos os processos em que a AGETRANSP e a AGENERSA figuravam como parte do feito. Nesta oportunidade, encontraram-se 202 processos.

A adoção de ambas as estratégias de pesquisa se explica. É que muitos casos envolvendo decisões de agências reguladoras estaduais são contestadas judicialmente não em face delas, mas do Estado do Rio de Janeiro. Além disso, há casos em que a impugnação de uma decisão de uma agência se dá apenas no processo judicial de cobrança desta multa, cuja legitimidade ativa é do ente central, i.e., do Estado do Rio de Janeiro, diante da ausência de lei delegando a capacidade tributária para a agência reguladora ${ }^{16}$. Ambas as hipóteses justificaram a pesquisa por meio da ferramenta de jurisprudência do Tribunal. Por outro lado, nem sempre o nome da agência consta da ementa. Noutras vezes, o nome é escrito incorretamente na transcrição do decisum. Daí porque foi necessária também a pesquisa pelos processos em que a agência consta como parte do feito.

Na oportunidade, com a junção dos resultados de ambos os métodos de pesquisa, foi identificado um total de 139 (cento e trinta e nove)

${ }^{16}$ APELAÇÃO CÍVEL. Embargos à execução fiscal. Multa administrativa aplicada pela Agência Reguladora de Energia e Saneamento Básico do Estado do Rio de Janeiro - AGENERSA, em razão de descumprimento de deveres relativos ao contrato de concessão. Alegação de ilegitimidade ativa do Estado para executar a multa sob fundamento de inconstitucionalidade material do art. 74 do Decreto 38.618/05 em face do que dispõe o art. 176, § $6^{\circ}$ da Constituição Estadual. Sentença de improcedência. Inconstitucionalidade que se rejeita. Dispensa de reserva de plenário na forma do art. 949, I do CPC/15 quando se rejeita tal arguição. Competência privativa da Procuradoria Geral do Estado para a inscrição, cobrança e execução da Dívida Ativa Estadual estabelecida no art. 176, § 6o da Constituição Estadual. Inconformismo da embargante que sustenta que o Estado não tem atribuição legal para inscrever e executar o crédito não-tributário relativo à autarquia, por ambos possuírem personalidades jurídicas distintas. Decreto 38.618/05 que regulamenta as competências da AGENERSA, e que, no art. 74, determina à Procuradoria Geral do Estado a representação judicial para a cobrança das multas aplicadas pela agência reguladora. A Lei Estadual 4.556/05, que criou a AGENERSA, estabelece as atribuições e responsabilidades da autarquia estadual, dentre elas a de fiscalização, com possibilidade de aplicação direta das sanções cabíveis. O crédito gerado pela imposição de multa passa a integrar a chamada dívida ativa não-tributária do ente público estadual, uma vez que ele é o detentor da competência tributária. Inexistência de delegação da capacidade tributária à AGENERSA, que não possui competência para inscrever multas em dívida ativa e nem para executálas. Legitimidade do Estado do Rio de Janeiro para executar os créditos inscritos em dívida ativa provenientes de multas aplicadas pela AGENERSA. Sentença mantida. DESPROVIMENTO DO RECURSO" (RIO DE JANEIRO, 2017b). 


\section{A TEORIA DA DEFERÊNCIA E A PRÁTICA JUDICIAL: UM ESTUDO EMPÍRICO SOBRE O CONTROLE DO TJRJ À AGENERSA}

processos nos quais havia uma análise judicial de uma decisão de uma agência reguladora estadual, assim entendidos como acórdãos proferidos em $2^{\underline{a}}$ instância, tanto em recursos de apelação ou em agravos de instrumento ${ }^{17}$. Desses casos relevantes, apenas 5 (cinco) se referiam à AGETRANSP, de modo que se preferiu limitar o escopo da pesquisa unicamente para os casos da AGENERSA. ${ }^{18}$ Chegou-se, pois, ao número final de 134 processos envolvendo decisões judiciais do TJRJ tendo por objeto algum ato praticado pela AGENERSA.

Algumas observações sobre os dados são necessárias. A primeira dela é relativa aos autores dos litígios. Apenas 1 das 134 demandas examinadas não foi ajuizada pela Companhia Distribuidora de Gás do Rio de Janeiro - $\mathrm{CEG}^{19}$. Isso demonstra que o contencioso da AGENERSA é praticamente focado no setor de gás canalizado - embora a agência também regule a atividade de outras concessionárias. Não foram identificados, no âmbito do TJRJ (em $1^{\underline{a}}$ ou $2^{\underline{o}}$ instância), litígios entre a AGENERSA (ou o Estado do Rio de Janeiro) e a Prolagos, Águas de Juturnaíba (abastecimento de água, coleta e tratamento de esgoto); e a Companhia Estadual de Águas e Esgotos (Cedae) que envolvam decisões da agência reguladora.

Outro ponto a ser destacado relaciona-se com a natureza das decisões administrativas contestadas judicialmente. De um total de 134 decisões,

\footnotetext{
17 Foram excluídos quatro blocos de decisões que não se adequaram à finalidade da pesquisa. Em primeiro lugar, não foram incluídos no bojo da pesquisa os casos em que se discutia a legitimidade ativa do Estado do Rio de Janeiro para a proposição de ações de execução fiscal das multas aplicadas pelas agências, uma vez que eles não relevam nenhuma característica específica da deferência do Poder Judiciário fluminense às agências. Em segundo lugar, foram igualmente excluídas as decisões que deferiram a suspensão da exigibilidade das multas aplicadas por agências reguladoras em função de realização de depósito judicial como garantia, uma vez que se trata de um direito potestativo do administrado conforme o disposto no art. 151 do Código Tributário Nacional. Em terceiro lugar, não foram catalogadas as decisões do TJRJ em demandas que envolvessem a antiga ASEP - Agência Reguladora de Serviços Públicos Concedidos do Estado do Rio de Janeiro. Por fim, não foram incluídas decisões de embargos de declaração que não alteraram o entendimento final do órgão colegiado sobre o resultado do julgamento.

${ }^{18}$ Todos esses resultados foram preenchidos em uma tabela com os seguintes campos: "número do processo"; "agência reguladora"; "discurso de deferência"; "amplitude de controle"; "natureza da decisão administrativa"; "parte autora"; "parte ré"; "cognição sumária/exauriente"; "decisão de 2 $2^{\underline{a}}$ instância"; "relator"; "órgão julgador"; "data da decisão"; e "observação". A combinação desses dados pode resultar em análises praticamente intermináveis sobre os resultados dessa pesquisa. No entanto, alguns pontos iniciais merecem destaque especial em relação aos resultados obtidos, os quais serão devidamente apresentados neste artigo.

19 No Agravo de Instrumento $\mathrm{n}^{\mathrm{O}}$ 0015408-17.2009.8.19.0000, o autor da ação foi a ABRAGET - Associação Brasileira de Geradoras Termelétricas.
} 


\section{REVISTA ESTUDOS INSTITUCIONAIS}

apenas 2 envolvem discussões quanto ao regime tarifário da $\mathrm{CEG}^{20-21} \mathrm{e}$ as demais envolvem exclusivamente a aplicação de penalidades pela AGENERSA à concessionária.

A natureza sancionatória de grande parte das decisões representa uma dificuldade metodológica adicional para o exame do nível de deferência do TJRJ à AGENERSA. Isso porque, do ponto de vista teórico, uma das grandes dificuldades do Poder Judiciário para lidar com decisões técnicas de autoridades administrativas independentes é a prospectividade de decisões regulatórias. De fato, é bastante comum que o regulador seja obrigado a realizar análises prognósticas, voltados a prever os efeitos de medidas governamentais ou operações empresariais em determinado setor do mercado. No entanto, as sanções administrativas não são dotadas de tais características. Embora multas e penalidades façam parte do ciclo regulatório (MOREIRA NETO, 2009, p. 444), sua natureza é mais próxima das medidas judiciais típicas, razão pela qual a sua submissão a um controle judicial não deferente é teoricamente menos problemática ${ }^{22}$.

No Direito Italiano, por exemplo, as sanções impostas pelas autoridades administrativas independentes estão necessariamente sujeitas a um tipo de controle judicial mais invasivo, em que o Poder Judiciário pode realizar um efetivo controle de mérito. Embora o Código de

20 No Agravo de Instrumento n⿳0 0015141-50.2006.8.19.0000, o recurso foi interposto decisão que indeferiu uma liminar em favor delas com relação à suspensão dos efeitos de diversos artigos das Deliberações AGENERSA de 2016, que versam acerca do momento correto para que os aumentos do preço do gás aplicados pela Petrobrás junto às agravantes possam ser repassados aos consumidores. Assim, a Desembargadora Relatora Helda Lima Meireles alegou que os fundamentos do juízo de primeira instância são os mesmos que foram utilizados para a concessão da liminar que foi cassada. Desse modo, as Deliberações da AGENERSA estariam em contradição com a decisão proferida no Ag. de Inst. citado no relatório. Portanto, a desembargadora dá provimento ao agravo para suspender a eficácia dos artigos $1^{\circ}, 2^{\circ}, 4^{\circ}$ e $5^{\circ}$ da Deliberação AGENERSA nํㅜ 16 e dos artigos $1^{\circ}, 3^{\circ}, 4^{\circ}$ e $5^{\circ}$ da Deliberação AGENERSA no 24 , ambas de 2006 (RIO DE JANEIRO, 2007).

${ }^{21}$ No Agravo de Instrumento $n^{\circ}$ 0015408-17.2009.8.19.0000, o recurso foi interposto contra decisão de $1^{\text {a }}$ instância que negou o pedido da agravante (Associação Brasileira de Geradoras Termelétricas) de declaração de nulidade de duas Deliberações da AGENERSA (nº 370 e 371 de 2009). O argumento da agravante é que os aumentos tarifários impostos por essas deliberações não são razoáveis pois não haverá benefícios às usinas térmicas. A medida foi negada sob o fundamento há presunção de legitimidade dos atos da Agência, que possui expertise técnica para análise dos impactos de aumentos tarifários. Além disso, fundamentou-se que as termelétricas têm capacidade patrimonial para suportar o ônus do ajuste promovido pela AGENERSA (RIO DE JANEIRO, 2009b).

22 Para uma análise sobre o controle judicial de sanções, ver Jordão (2016, p. 132-136). 


\section{A TEORIA DA DEFERÊNCIA E A PRÁTICA JUDICIAL: UM ESTUDO EMPÍRICO SOBRE O CONTROLE DO TJRJ À AGENERSA}

Processo Administrativo italiano tenha um reduzido rol de hipóteses de aplicação de um controle forte, fato é que, até hoje, é possível o exercício de um controle pleno sobre as sanções administrativas - o que é corroborado pela jurisprudência do seu Conselho de Estado. ${ }^{23}$

Trata-se, pois, de uma peculiaridade adicional para o objeto de pesquisa em questão. Mesmo que os dados analisados revelem algumas tendências na atuação do TJRJ em relação à AGENERSA, a natureza sancionatória da grande maioria das decisões regulatórias judicializadas pode sugerir alguma cautela sobre as conclusões a propósito da existência ou não de uma postura autocontida do Judiciário fluminense em relação à generalidade de medidas administrativas. Esse obstáculo será considerado nas ponderações finais do presente trabalho, adotando-se o alerta de que os dados analisados não podem ser transpostos acriticamente para outros tipos de atividade regulatória, tal como, v.g., a produção normativa ou uma decisão sobre um pleito de equilíbrio econômico-financeiro de um contrato de concessão.

Conforme apresentado na introdução, a deferência judicial às agências reguladoras é um fenômeno de difícil identificação. Trata-se de um processo complexo e multifacetado que, muitas vezes, requer a avaliação de diversas variáveis para que se possam identificar seus indícios.

Para os fins do presente artigo, os dados obtidos serão classificados, primeiramente, em função da existência de um (1) discurso de deferência no Tribunal de Justiça do Estado do Rio de Janeiro. Há três subgrupos estabelecidos no objeto de análise do estudo: (1.i) decisões que adotaram um discurso de deferência específico para as agências reguladoras baseada em aspectos institucionais da entidade (discurso de deferência específico), representando 11,94\% dos casos; (1.ii) decisões que adotaram um discurso de deferência com base em uma ideia geral de separação dos poderes e autorrestrição em relação à Administração Pública como um todo (discurso de deferência genérico), que abrangem 40,3\%. Nessa segunda hipótese, um dos principais argumentos utilizados para sugerir uma moderação do controle judicial incidente sobre a Administração Pública baseia-se numa suposta violação ao princípio da separação dos Poderes. A construção do raciocínio é bastante conhecida: uma supervisão judicial muito intensa sobre as decisões administrativas poderia construir uma intromissão do Poder Judiciário nos afazeres do

23 Consiglio Stato/Cons. St., Sez. VI, 23.4.2002, n. 2199, item. 1.3.1. Afirma-se que a aplicação de um controle pleno sobre as sanções administrativas é uma tradição do Direito Italiano. De acordo com a decisão do Conselho de Estado, a razão para maior intervenção judicial se extrai diretamente do art. 23 da Constituição italiana, que protege o direito dos cidadãos de não sofrer decréscimos patrimoniais fora dos casos previstos na lei. Resta clara, portanto, a incidência de um controle particularmente intenso para a proteção de direitos de ordem constitucional. O Controle judicial se fará com base nos critérios da lei de referência para o estabelecimento da sanção. 


\section{REVISTA ESTUDOS INSTITUCIONAIS}

JULHO/DEZEMBRO - ISSN 2447-5467

Poder Executivo, e essa circunstância causaria um desequilíbrio entre os Poderes do Estado. Por fim, há (1.iii) decisões que não adotaram qualquer tipo de discurso de deferência em suas razões de decidir (discurso de deferência ausente), representadas na porcentagem de 47,76\%.

Mas o discurso não representa, per se, uma postura respeitosa dos Tribunais em relação às agências reguladoras. A uma, porque é possível que haja deferência sem a adoção de um discurso - até porque, ao contrário de outros países, o Brasil não possui um precedente paradigmático ou um entendimento doutrinário pacífico sobre a existência efetiva de uma teoria da deferência com um (ou mais) parâmetro(s) claro(s) de aplicação. A duas, porque a mera existência de um discurso não é garantia para a efetiva conduta deferencial do Poder Judiciário. Nem sempre a adoção do discurso condirá com uma postura respeitosa do tribunal.

Portanto, em segundo lugar, examinar-se-á a deferência dos Tribunais a partir da prática, sob duas óticas distintas.

A primeira delas avaliará a (2) deferência pelo resultado. Nesse caso, a deferência denota não uma postura ou atitude judicial específica em relação às decisões administrativas controladas, mas uma específica solução judicial depois de operado o controle. Deferência, nesse sentido, corresponde precisamente à manutenção da decisão administrativa contestada judicialmente. Aqui, deferir à administração significa não anular (ou não suspender) sua decisão. Nesse ponto, as classificações foram definidas como (2.i) deferentes - "manutenção da decisão" $(90,23 \%)$; e (2.ii) não deferentes - "anulação ou suspensão da decisão" $(9,77 \%)$.

Essa não é, contudo, a única (ou a melhor) forma de avaliar a deferência de uma corte diante de uma decisão de uma autoridade regulatória. Com efeito, a postura autorrestritiva não implica necessariamente a manutenção da decisão administrativa. É possível que o tribunal chegue à conclusão de que a ela não fora, .e.g., razoável, levando à sua anulação.

Em razão disso, a pesquisa incluiu outra variável relevante para a análise do objeto desse artigo: a existência de (3) deferência pela amplitude de controle do Tribunal de Justiça do Estado do Rio de Janeiro nas decisões investigadas. Isto é: se o Poder Judiciário fluminense, independentemente da adoção de um discurso de deferência ou do resultado do julgamento, possui uma atitude autocontida em relação à extensão do seu controle sobre as decisões proferidas pela AGENERSA. Acórdãos que levaram em conta apenas os aspectos formais e procedimentais foram classificados como (3.i) "controle formal" $(60,45 \%)$. Já os julgados em que os magistrados levaram em conta aspectos 


\section{A TEORIA DA DEFERÊNCIA E A PRÁTICA JUDICIAL: UM ESTUDO EMPÍRICO SOBRE O CONTROLE DO TJRJ À AGENERSA}

substanciais da decisão, muitas vezes com base em avaliações próprias de razoabilidade ou de juízos pessoais sobre a questão posta em julgamento, foram classificadas como (3.2) "controle substantivo" (39,55\%). Nesse ponto, são consideradas também decisões proferidas em juízo cognitivo sumário tendentes a permitir a produção de provas para uma futura avaliação da correção da conduta da agência ${ }^{24}$.

De fato, o controle da substância da ação administrativa controlada, de seu objeto ou de seu conteúdo releva uma postura mais intrusiva do Poder Judiciário do que aquela que se dedica ao controle de forma, menos problemática sob o ponto de vista da deferência judicial. Isso porque esse tipo de controle não envolve a revisão de escolhas públicas, mas, e.g., de vícios procedimentais ou de violações ao dever de motivação ${ }^{25}$. Em algumas jurisdições ${ }^{26}$, tem-se investido no controle forte das garantias procedimentais dos particulares como forma de compensar a limitação do controle substancial aplicado sobre algumas decisões administrativa. Trata-se de uma forma de atuação que incentiva um processo decisório transparente e bem informado sem, no entanto, enfrentar o seu conteúdo ou mérito ${ }^{27}$.

Pois bem. Em cada uma dessas variáveis, foram destrinchadas, ainda, as decisões finais proferidas em sede de cognição sumária e de cognição exauriente. Processos judiciais envolvem, muitas vezes, pedidos liminares formulados pelo autor da ação requerendo a adoção de medidas urgentes pelo Poder Judiciário. Tais decisões chegam à $2^{\underline{a}}$ instância, na maioria das vezes, por meio de agravos de instrumento. Em alguns casos, a deferência judicial é ligada a um discurso de presunção de legitimidade dos atos administrativos ${ }^{28}$. Essa presunção, geralmente,

${ }^{24}$ É o caso, por exemplo, do Processo no 0257608-18.2010.8.19.0001. Na oportunidade, a $1^{\text {a }}$ Câmara Cível anulou a sentença proferida em $1^{1}$ instância em razão de vícios na fase probatória. O TJRJ determinou a remessa dos autos ao juízo de piso para a realização efetiva da produção de provas, com o intuito de que, ao final, o magistrado sentenciante pudesse fazer uma verdadeira análise da substância da decisão da agência, concordando com ela a partir dos elementos probatórios apresentados em perícia.

${ }_{25}$ Ambas as garantias são previstas, no Brasil, na Lei de Processos Administrativos Federal (Lei no 9.784/99) e, mais especificamente, na Lei do Estado do Rio de Janeiro n⿳o 5.427/09. Confira-se a redação de seu art. 2‥ "Art. $2^{\circ} \mathrm{O}$ processo administrativo obedecerá, dentre outros, aos princípios da transparência, legalidade, finalidade, motivação, razoabilidade, proporcionalidade, moralidade, ampla defesa, contraditório, segurança jurídica, impessoalidade, eficiência, celeridade, oficialidade, publicidade, participação, proteção da confiança legítima e interesse público" (Grifouse).

${ }^{26}$ É o caso da França. Sobre o assunto, ver Jordão (2016, p. 109-122).

27 Sobre o tema, ver Jordão e Rose-Ackerman (2014, p. 01-72). Em favor deste modelo no Canadá, ver Mullan (1998).

${ }^{28}$ Carvalho Filho (2017, p. 124) anota que "[o]s atos administrativos, quando editados, trazem em si a presunção de legitimidade, ou seja, a presunção de que nasceram em conformidade com as devidas normas legais (...) Essa característica não depende de lei 


\section{REVISTA ESTUDOS INSTITUCIONAIS}

corresponde a duas dimensões de análise: a veracidade dos fatos que basearam a tomada de decisão; e a pressuposição de que, salvo manifesta irrazoabilidade, o ato é válido, legal e constitucional. Nesses casos, ante a ausência de um juízo definitivo sobre o assunto, seria possível a suspender cautelarmente uma decisão administrativas apenas em casos de urgência e existência de dúvida séria sobre a sua legalidade ${ }^{29}$. Como se verá a seguir, as decisões proferidas em sede de cognição sumária (35 processos) possuem uma maior incidência de discurso de deferência e de controle estritamente formal do que em relação às decisões proferidas de maneira definitiva (99 processos). Isso, contudo, importa em uma margem muito reduzida de diferença quanto à efetiva revisão judicial dos atos da AGENERSA.

Estabelecidas tais premissas, passa-se à análise efetiva dos resultados obtidos.

\section{A DEFERÊNCIA Do Tribunal DE Justiça do Estado do RIO DE JANEIRO À AGENERSA}

\section{Deferência pelo discurso}

A primeira variável analisada na pesquisa foi a presença ou não de um discurso deferente às agências reguladoras nas decisões do TJRJ proferidas em $2^{\underline{a}}$ instância em processos envolvendo a AGENERSA. A presença do discurso (de forma específica ou genérica) foi identificada em 72 dos 134 processos selecionados, o que representa um percentual de $52,24 \%$. Nos demais 62 , não foi possível identificar qualquer razão de decidir fundada na especialidade técnica da autoridade reguladora ou na impossibilidade de revisão das decisões do Poder Executivo como um todo, totalizando $47,76 \%$ dos casos.

$\mathrm{O}$ discurso de deferência pode estar presente tanto em uma decisão que resolva o mérito da ação como em uma decisão que aprecie uma questão incidente do processo, da qual não resultará necessariamente um julgamento definitivo do caso. Esse discurso de autorrestrição pode ser extraível, por exemplo, em trecho da decisão do Processo no 0158503 92.2015.8.19.0001, de relatoria do Desembargador Custódio de Barros Tostes, da 1a Câmara Cível, em que se destaca que não cabe ao Poder

expressa, mas deflui da própria natureza do ato administrativo, como ato emanado de agente integrante da estrutura do Estado"

29 Segundo Jean Waline (2010, p. 419), o mesmo se dá na França a partir da noção da presunção de conformidade dos atos administrativos com o direito (bénéfice du préalable). 


\section{A TEORIA DA DEFERÊNCIA E A PRÁTICA JUDICIAL: UM ESTUDO EMPÍRICO SOBRE O CONTROLE DO TJRJ À AGENERSA}

Judiciário avaliar decisões técnicas das agências reguladoras a ponto de dispensar uma perícia para reavaliá-la:

(...) sabe-se que, na sindicância dos atos administrativos, o Poder Judiciário deve se limitar aos aspectos de legalidade, sem avançar à sua avaliação de mérito, este que, por força da separação dos poderes, é infenso ao controle judicial. A toda evidência, o debate é puramente de direito e, nesta medida, dispensa instrução. Até porque, note-se, a produção de prova pericial apenas seria necessária para subsidiar o debate acerca da justiça da decisão administrativa, notadamente quanto à evidência técnica de que a apelante falhara na prestação de serviço. A esta altura, já se teria desbordado dos limites impostos à atividade judicante, sobrepondo-a à da autoridade executiva. (RIO DE JANEIRO, 2017a)

Pois bem. Como explicado na seção anterior, o discurso de deferência pode se apresentar de duas formas distintas, segundo a classificação adotada neste artigo. A primeira delas foi classificada como um discurso de deferência específico, em que a linha de argumentação adotada pelos desembargadores reconhece a necessidade de uma postura autocontida do tribunal em respeito às capacidades institucionais das agências reguladoras para lidar com temas técnicos e complexos. Tal circunstância foi identificada em um total de 16 processos, representando $11,94 \%$ das decisões catalogadas.

No processo de número 0393122-64.2015.8.19.0001, por exemplo, a Desembargadora Myriam Fonseca Costa destaca algumas características das agências como relevantes para que se assuma posição de deferência às agências:

A independência, especialidade, caráter técnico, amplo poder normativo, poder de resolução de demandas administrativas, entre outros, [que] encontram fundamento na função reguladora estatal, inerente ao exercício do poder de polícia. (TJRJ, Processo $\mathrm{n}^{\circ}$ 0393122-64.2015.8.19.0001, Rel. Des. Myriam Medeiros da Fonseca Costa, $4^{\text {a }}$ Câmara Cível, j. em 01/02/2017)

O mesmo se dá no Processo n⿳o 0099399-53.2007.8.19.0001, em que o relator Desembargador Ferdinaldo do Nascimento destaca que:

O modelo regulatório adotado no Brasil veio inserido dentro de um contexto de desestatização do serviço público, que passou a ser desempenhado pelo 


\section{REVISTA ESTUDOS INSTITUCIONAIS}

JULHO/DEZEMBRO - ISSN 2447-5467

particular, ficando o Estado com o planejamento e a regulamentação destas atividades. O serviço, que é público, torna-se passível de ser realizado pelo particular devendo este, para tanto, submeter-se à regulação e fiscalização por parte das autarquias em regime especial, criadas para tal finalidade. (TJRJ, Processo $\mathrm{n}^{\mathrm{o}}$ 0099399-53.2007.8.19.0001, Rel. Des. Ferdinaldo do Nascimento, 19ª Câmara Cível, j. em $19 / 05 / 2012)$

Em uma segunda hipótese, a deferência como discurso pode se apresentar de forma mais genérica, calcada não em razão das agências reguladoras como autoridades desenhadas para lidar com questões técnicas específicas, mas sim em uma necessidade geral de uma postura autocontida do Poder Judiciário em relação à Administração Pública. Nesse sentido, são identificadas decisões judiciais fundamentadas no princípio da separação dos poderes, ou na impossibilidade de controle do mérito administrativo. $\mathrm{O}$ discurso de deferência genérico foi identificado em 54 dos 134 processos catalogados, resultando em um percentual total de $40,30 \%$.

No Processo $\mathrm{n}^{\mathrm{o}}$ 0134262-54.2015.8.19.0001, de relatoria do Desembargador Benedicto Ultra Abicair, o discurso de deferência utilizado girou em torno da própria natureza do ato administrativo discricionário que pode provir de qualquer órgão da Administração. $\mathrm{O}$ relator ressalta que ao Judiciário cabe unicamente verificar a legalidade e legitimidade do ato, de modo a analisar se este está ou não em conformidade com a lei ${ }^{30}$.

Outro exemplo seria o julgado do Processo no $0239612-$ 65.2014.8.19.0001. A relatora do caso, Desembargadora Sirley Abreu Biondi, justifica que o Poder Judiciário, ao analisar decisão administrativa, deve restringir-se a observar se houve ou não respeito ao devido processo legal, à razoabilidade e à proporcionalidade da multa imposta pela agência, tudo isso em nome das limitações impostas pela separação de poderes que, em suas palavras "impede o Judiciário de se

\footnotetext{
30 “No mérito, tem-se que o controle dos atos administrativos pelo Poder Judiciário tem como intuito, unicamente, a verificação da legalidade ou ilegitimidade do ato, analisando-se a conformidade deste com a norma legal que o rege, sendo certo que não deverá invadir os aspectos que são reservados à apreciação subjetiva da Administração Pública, conhecidos como o mérito do ato, ou seja, a oportunidade e a conveniência". (RIO DE JANEIRO, 2016b)
} 


\section{A TEORIA DA DEFERÊNCIA E A PRÁTICA JUDICIAL: UM ESTUDO EMPÍRICO SOBRE O CONTROLE DO TJRJ À AGENERSA}

imiscuir nas questões de mérito de atribuição da Administração Pública" (RIO DE JANEIRO, 2016d).

Quando destrinchados esses elementos entre apelações cíveis (cognição exauriente) e em agravos de instrumento (cognição sumária), é possível notar uma maior incidência de decisões que adotam discursos de deferência nos casos em que os magistrados são postos a examinar a validade do ato administrativo no início do processo, quando ainda não instaurado o contraditório ou não produzidas todas as provas.

Dos 99 casos em que as decisões judiciais foram proferidas em sede de cognição exauriente, 48 delas adotaram um discurso de deferência $(48,48 \%)$, sendo 13 delas a partir de um motivo específico alinhado às capacidades institucionais das agências reguladoras $(13,13 \%)$, e 35 por razões genéricas já mencionadas $(35,35 \%)$. Por outro lado, 51 dos processos examinados resultaram em decisões finais em que não foi possível identificar qualquer fundamentação neste sentido $(51,52 \%)$.

Já nos processos em que foram proferidas decisões em sede de cognição sumária (agravos de instrumento), os discursos judiciais de deferência aos atos administrativos da AGENERSA se correlacionam tanto com o desenho das agências para lidar com questões técnicas e complexas, como também por meio do reconhecimento da presunção de legitimidade dos atos administrativos. Em um exemplo, confira-se a decisão proferida no Processo $\mathrm{n}^{\mathrm{o}}$ 0056600-51.2014.8.19.0000, em que ambos os fundamentos foram adotados pela 22 ${ }^{a}$ Câmara Cível do TJRJ:

(...) o deferimento de pedido de antecipação dos efeitos da tutela contra ato administrativo reclama prova inequívoca de sua ilegalidade ou desproporcionalidade, considerando que os atos estatais são dotados da presunção de legitimidade, estando, em princípio, de acordo com a lei e com a realidade" (...) Ressalte-se que a complexidade dos fatos motivadores da sanção aplicada impede que no âmbito estreito do agravo de instrumento se aprecie a alegada nulidade do ato administrativo. (RIO DE JANEIRO, 2015a)

Dos 35 processos identificados com decisões proferidas em sede de cognição sumária, 24 apresentavam discurso de deferência $(68,57 \%)$, sendo 3 delas com base em um discurso específico (8,57\%) e 21 fundadas em um discurso genérico (60\%). Apenas 11 não adotam qualquer discurso de deferência $(31,43 \%)$. Nesse ponto, merece destaque o Processo $\mathrm{n}^{\mathrm{o}}$ 0045368-42.2014.8.19.0000, no qual a 21 ${ }^{\text {a }}$ Câmara Cível prescreveu que questões técnicas devem ser aferidas pela agência reguladora - que tem atribuição para determinar a adoção de medidas relativas à atividade desenvolvida pelo setor regulado (RIO DE JANEIRO, 2015b). Igualmente, no Processo $n^{0}$ 0051790-72.2010.8.19.0000, afirmou-se que 


\section{REVISTA ESTUDOS INSTITUCIONAIS}

a Agência Reguladora é órgão técnico especializado e a mera suspensão de suas decisões, sem maiores fundamentos, pode traduzir verdadeira intervenção do Poder Judiciário em seara que não lhe é reservada. (RIO DE JANEIRO, 2011)

\section{Gráfico 1 - Comparação entre os tipos de discurso}

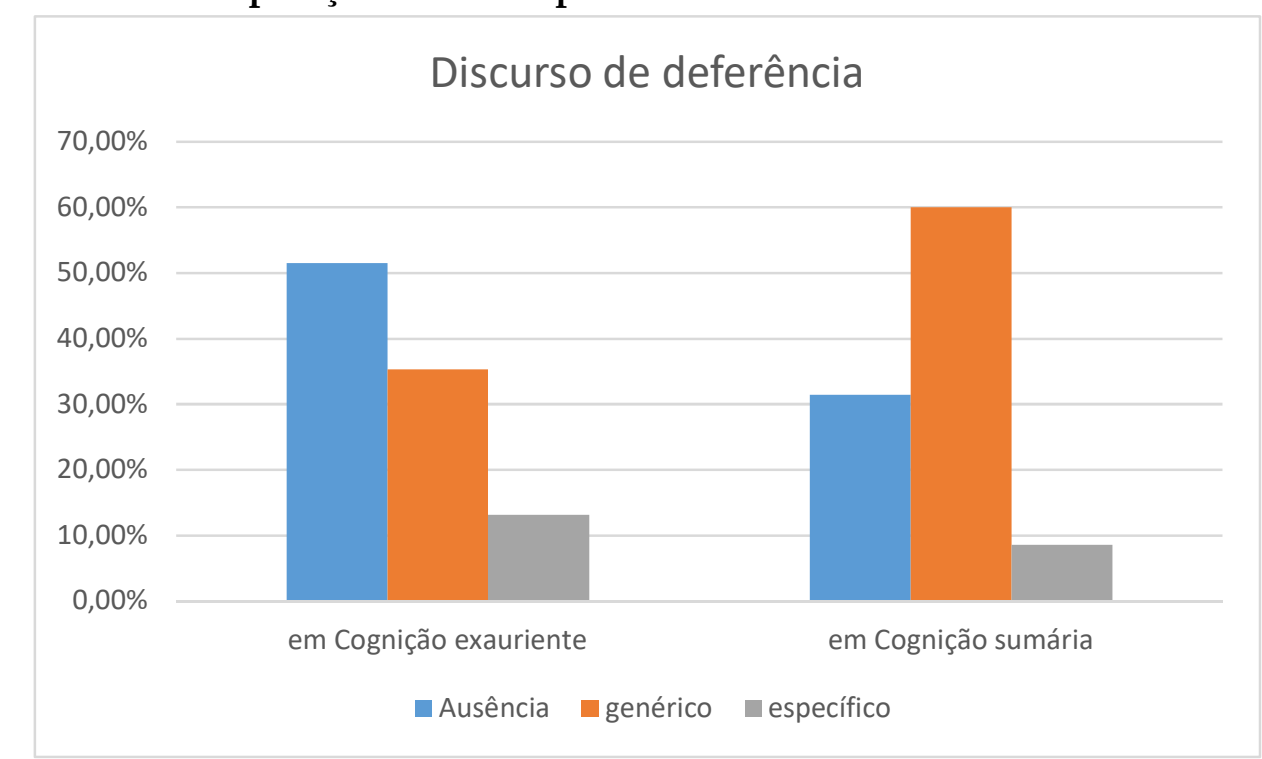

Fonte: elaborado pelos autores

\section{Deferência pelo resultado}

Como já afirmado, o discurso de deferência não é garantia de uma atuação autocontida dos tribunais. É em razão dessa circunstância que os estudos empíricos que avaliam a eficácia da doutrina deferencial nos tribunais também inserem como variável de análise a deferência pelo resultado, isto é, uma análise do percentual de manutenção e revisão destas decisões administrativas sob controle.

Analisando os dados levantados, foi possível constatar que a grande maioria dos casos resultou na manutenção das decisões da AGENERSA. De um universo total de 133 decisões $^{31}$, 120 processos resultaram em

${ }^{31} \mathrm{O}$ universo total de decisões para a análise da deferência pelo resultado se explica. $\mathrm{O}$ Processo $n^{\circ}$ 0257608-18.2010.8.19.0001 foi excluído desse tópico de análise porque a decisão obtida não resultou na manutenção ou anulação da decisão da AGENERSA. 


\section{A TEORIA DA DEFERÊNCIA E A PRÁTICA JUDICIAL: UM ESTUDO EMPÍRICO SOBRE O CONTROLE DO TJRJ À AGENERSA}

entendimento favorável à interpretação conferida pela agência reguladora estadual $(90,23 \%)$, enquanto apenas 13 demandas decididas pelo TJRJ tiveram como resultado a anulação de seus atos $(9,77 \%)$.

Quando analisados tais dados em sede de cognição sumária ou exauriente, as variações percentuais não se afastam muito do quadro geral. Em apelações cíveis, o índice de revisão representa um total de apenas 8 decisões $(8,16 \%)$, enquanto 90 delas foram favoráveis à AGENERSA. Já em agravos de instrumento, a penas 5 decisões resultaram na suspensão cautelar de decisões das agências reguladoras $(12,5 \%)$, enquanto 30 as mantiveram hígidas ao longo do processo judicial $(87,5 \%)$.

No Agravo de Instrumento $\mathrm{n}^{\mathrm{o}}$ 0010860-70.2014.8.19.0000, por exemplo, o Desembargador Paulo Mauricio Pereira decidiu pela suspensão da eficácia de Deliberação da AGENERSA (Deliberação 966/2012), que havia determinado à CEG a tomada de providências tendentes a evitar a repetição do acidente em que ocorreu uma explosão provocada por escapamento de gás. De acordo com o relator, "nenhum ato omissivo ou comissivo pode[ria] ser atribuído à concessionária e que pudesse justificar, a princípio, às determinações constantes da deliberação", de modo que foi vislumbrado "perigo de dano iminente para a agravante, caso venha a ser penalizada com eventual multa por não tomar as vagas providências" (RIO DE JANEIRO, 2014).

Gráfico 2 - Comparação entre os diferentes tipos de resultado

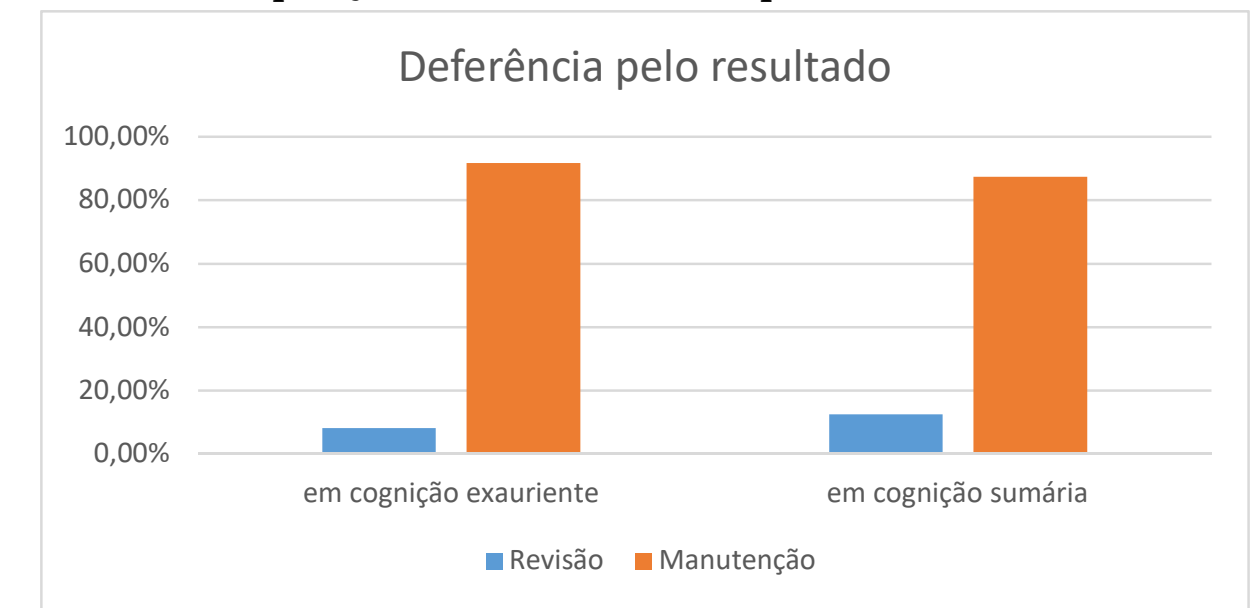

Fonte: elaborado pelos autores

Na oportunidade, a $1^{\text {a }}$ Câmara Cível anulou a sentença proferida em $1^{\text {a }}$ instância em razão de vícios na fase probatória. O caso em questão foi incluído na base de dados porque, para os demais tópicos de análise, foi possível verificar (i) que não foi adotado um discurso de deferência nas razões de decidir do acórdão; e (ii) admitiu-se a produção de provas para que o magistrado sentenciante possa fazer uma verdadeira análise da substância da decisão da agência, concordando com ela a partir dos elementos probatórios apresentados em perícia. 


\section{REVISTA ESTUDOS INSTITUCIONAIS}

\section{Deferência pela amplitude de controle}

Ser deferente não significa, necessariamente, manter a decisão de uma agência reguladora. Decisões irrazoáveis podem vir a ser anuladas sem que isso resulte em uma postura intrusiva dos tribunais. Além disso, é possível que uma orientação deferencial se extraia da delimitação do controle aos aspectos formais das decisões administrativas controladas. A anulação, por exemplo, de atos proferidos fora da esfera de competências atribuídas pelo legislador à autoridade administrativa não representa uma forma de controle que importe numa atitude contrária àquela defendida pela teoria da deferência. $O$ mesmo se diga em relação à decisões judiciais que invalidem a conduta da agência reguladora por inobservância às garantias processuais (devido processo legal, do contraditório, da ampla defesa) ou a um dever de motivação adequada. Por conta de tais circunstâncias, a verificação da amplitude de controle é uma terceira variável que pode vir a demonstrar a deferência do TJRJ à AGENERSA.

Em um total de 134 processos catalogados, 81 levaram a um julgamento estritamente sobre aspectos formais da atuação da AGENERSA (60,45\%). Nesses casos, o TJRJ acaba de certa forma sendo respeitoso à decisão da agência, ao não se imiscuir no objeto específico da decisão. Para exemplificar melhor tal categoria, confira-se o seguinte trecho do Processo no 0016514-33.2017.8.19.0000, em que a decisão da AGENERSA foi mantida apenas porque

foi assegurado ao agravante [CEG] o direito à ampla defesa e ao devido processo legal, diante das previsões contidas nos artigos $5^{\circ}$, inciso LV, da CRFB/88, $2^{\circ}$, da Lei Estadual no 5.427/2009 e artigo 13, da Instrução Normativa Agenersa no 01/2007. (TJRJ, Processo $\mathrm{n}^{\mathrm{o}}$ 0016514-33.2017.8.19.0000, Rel. Des. Paulo Sérgio Prestes dos Santos, 2 ${ }^{a}$ Câmara Cível, j. em 24/05/2017)

Já em 53 demandas, o controle do TJRJ foi calcado em aspectos materiais da decisão proferida pela AGENERSA, compreendendo, portanto, controle substantivo sobre sua atuação (39,55\%). Assim, no Processo $\mathrm{n}^{\mathrm{o}}$ 0082085-50.2014.8.19.0001, por exemplo, a Des. Relatora Sirley Abreu Biondi afirmou que

[d]as provas colacionadas aos autos emergiu a conclusão de que a autora/apelante realmente descumpriu as normas contratuais, razão pela qual se infere que a multa 


\section{A TEORIA DA DEFERÊNCIA E A PRÁTICA JUDICIAL: UM ESTUDO EMPÍRICO SOBRE O CONTROLE DO TJRJ À AGENERSA}

foi bem aplicada e em patamares razoáveis. (TJRJ, Processo $\mathrm{n}^{\mathrm{o}}$ 0082085-50.2014.8.19.0001, Rel. Des. Sirley Abreu Biondi, 13ª Câmara Cível, j. em 14/10/2015)

Já no Processo nº 0473492-35.2012.8.19.0001, o relator considerou que havia "fundamento fático" (além do jurídico) à imposição das sanções administrativas de advertência e de multa à CEG, considerando o atraso de mais de um ano na prestação do serviço contratado no caso concreto (RIO DE JANEIRO, 2015c). Nestes casos, de forma mais explícita ou não, os magistrados demonstram que os aspectos substanciais da atuação a AGENERSA foram elementos essenciais para o resultado final do processo.

Quando apurados os casos a partir do tipo de cognição da decisão judicial, é possível notar uma margem relevante a favor do controle meramente formal em agravos de instrumento. Com efeito, nas apelações cíveis, 56 de um total de 99 processos tiveram decisões cujo controle foi estritamente formal (56,57\%), enquanto 43 deles envolveram também controle sobre aspectos substantivos da atuação da AGENERSA (43,43\%). De outro lado, decisões em sede de juízo sumário levaram a 25 processos em que o controle judicial repousou apenas sobre aspectos de forma $(71,43 \%)$. Apenas 10 julgados se fundaram num juízo relativo à substância da decisão da agência $(28,57 \%)$.

Gráfico 3 - comparação entre as diferentes amplitudes de controle

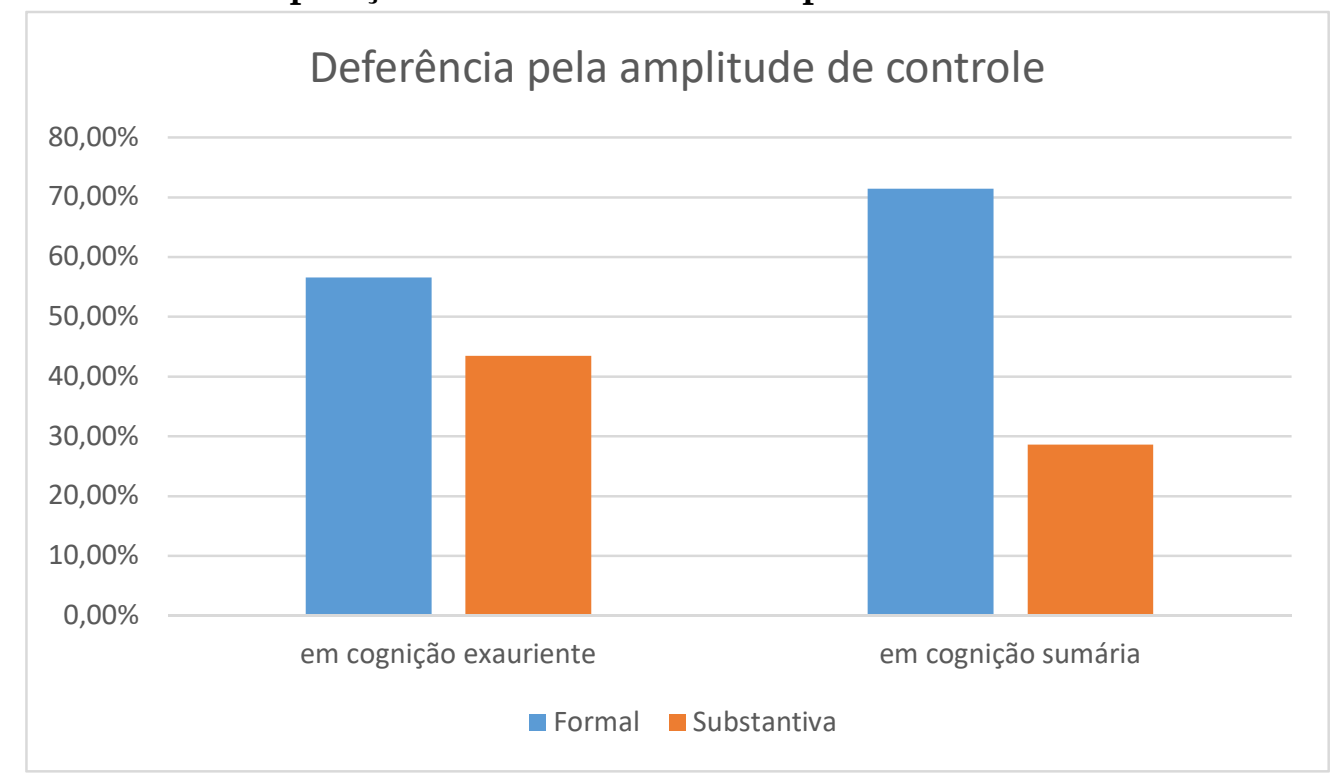

Fonte: elaborado pelos autores. 


\section{REVISTA ESTUDOS INSTITUCIONAIS}

\section{Conjugação das variáveis e possíveis tendências do TJRJ}

Este último subitem do artigo está destinado à conjugação das variáveis pesquisadas, de modo a decompor possíveis orientações extraíveis do conjunto de julgados do TJRJ em relação à AGENERSA. As questões que serão examinadas são as seguintes: (i) qual o impacto da adoção do discurso de deferência no resultado e na amplitude do controle? (ii) qual a variação do impacto do discurso da deferência em função de sua natureza genérica ou específica? (iii) qual a relação entre a amplitude do controle e o seu resultado final?; (iv) há um maior índice de deferência nas decisões de cognição sumária ou exauriente?

\subsection{O impacto da adoção do discurso de deferência no resultado e na amplitude do controle}

A primeira questão que precisa ser enfrentada tem a ver com a medida em que o discurso de deferência (primeiro dos critérios utilizados para identificar a orientação judicial deferente) é determinante para um resultado deferente e para um controle pouco amplo. Trata-se de verificar como o primeiro dos critérios utilizados para identificar a orientação judicial deferente (o discurso) se relaciona com os demais (resultado final do controle e amplitude do controle).

$O$ fato dos tribunais adotarem um discurso deferente não implica, necessariamente, que eles adotarão também uma postura deferente no que concerne ao resultado e à amplitude do controle. Exemplo disso é o Processo no 0364944-08.2015.8.19.0001, em que o Desembargador Relator Cláudio Luiz Braga Dell'orto consignou que

descabe ao Judiciário avaliar os parâmetros adotados pela administração quando da fixação da multa, sendo-lhe vedado substituir a valoração técnica do órgão regulador, salvo se houver manifesta ofensa aos princípios da razoabilidade e proporcionalidade. (RIO DE JANEIRO, 2017c)

No entanto, ao votar pela manutenção da decisão da AGENERSA, foram reavaliados todos os fatos que levaram à aplicação da penalidade ${ }^{32}$,

\footnotetext{
32"Portanto, detalhada a falha nos serviços prestados pela recorrente, que se omitiu diante da reclamação do usuário, correta a aplicação de sanção administrativa pela agência reguladora. Revela-se infundada a alegação de violação ao princípio da legalidade, por ausência de motivação específica do ato punitivo, haja vista que a
} 


\section{A TEORIA DA DEFERÊNCIA E A PRÁTICA JUDICIAL: UM ESTUDO EMPÍRICO SOBRE O CONTROLE DO TJRJ À AGENERSA}

em verdadeiro juízo de correção sobre a atuação da agência, característico de um controle amplo. O resultado favorável, portanto, não se deu porque o tribunal foi deferente à AGENERSA, mas sim porque o órgão colegiado concordou com as razões que a levaram a tomar aquela decisão.

As variáveis pesquisadas neste artigo revelam esse tipo de comportamento judicial que pode parecer contraditório. De um total de 72 decisões em que o discurso de deferência foi adotado pelo tribunal, 20 acabaram por avaliar substancialmente a decisão da agência reguladora (27,78\% dos casos), em aplicação de um controle amplo. Isso quer dizer que nem sempre a consciência do magistrado quanto à necessidade de uma postura autocontida o leva a realizar um controle meramente formal da decisão da agência.

A relação entre o critério da deferência pelo discurso e pelo resultado revela um cenário diferente. Dentre os 72 processos que adotaram o discurso de deferência, apenas 1 caso levou à revisão judicial do ato praticado pela autoridade administrativa (resultado não deferente). $\mathrm{Ou}$ seja, 98,61\% dos casos foram decididos favoravelmente à agência. Mais do que isso, o único caso em que a demanda foi julgada favorável à CEG na presença de um discurso de deferência, o vício encontrado na decisão administrativa foi de natureza procedimental: segundo a $4^{\mathrm{a}}$ Câmara Cível, seria válida a anulação de uma penalidade aplicada pela AGENERSA exclusivamente em razão de sua conduta contraditória. Segundo o acórdão, a agência teria reconhecido, inicialmente, a culpa da concessionária no processo sancionador e, ao mesmo tempo, teria determinado a juntada de novos documentos para abertura de um novo processo para cuidar da aplicação de nova penalidade com base nos mesmos fatos (RIO DE JANEIRO, 2009a). Parece haver uma forte correlação, portanto, entre a adoção de um discurso deferencial e um resultado final pró-agência.

Para avaliar o verdadeiro impacto da adoção do discurso de deferência, no entanto, é preciso comparar estes números com os números relativos aos processos em que este discurso está ausente. Em um universo de 62 processos cujas decisões não adotaram discurso de deferência, apenas 12 tiveram como resultado final a revisão ou suspensão da decisão lavrada pela AGENERSA (índice de deferência pelo resultado de $80,33 \%$ ). Já em relação à amplitude de controle, a mudança de postura é mais significativa: menos da metade dos processos (30 em um total de 62) em que não foi adotado um discurso de deferência tiveram um controle exclusivamente de forma (índice de deferência pela amplitude de $48,39 \%$ ).

punição decorreu, como ficou expressamente consignado no processo administrativo, de falha na prestação do serviço, qual seja, omissão na prevenção de acidente, já que mesmo tendo sido previamente acionada pelo usuário, só compareceu ao imóvel deste, de forma eficaz, no dia em que houve uma explosão em virtude de vazamento de gás" (RIO DE JANEIRO, 2017c). 


\section{REVISTA ESTUDOS INSTITUCIONAIS}

JULHO/DEZEMBRO - ISSN 2447-5467

É possível afirmar, portanto, que a adoção de um discurso de deferência leva a um percentual maior de manutenção de decisões da AGENERSA $(98,61 \%)$ do que nos casos em que o discurso é ausente $(80,33 \%)$. É possível dizer o mesmo em relação à amplitude reduzida de controle (72,22\% versus $48,39 \%)$. Isso releva uma relação tendencial significativa entre discurso e postura do TJRJ - quando a primeira variável está presente, há uma maior propensão do tribunal a ser mais deferente na perspectiva do resultado e da amplitude do controle.

\subsection{A variação do impacto do discurso da deferência em função de sua} natureza genérica ou específica

Como foi visto anteriormente, a pesquisa identificou a presença de dois tipos diferentes de discurso de deferência: um discurso deferencial genérico, que defende a conveniência de uma atitude judicial respeitosa em relação às decisões de quaisquer autoridades administrativas; e um discurso deferencial específico, que atrela a suposta conveniência de respeitar as decisões das agências reguladoras às características específicas desta espécie de entidade administrativa.

Neste subitem, o interesse está voltado à identificação da medida em que a variação deste discurso deferencial pode impactar o resultado e a amplitude do controle. $\mathrm{O}$ reconhecimento pelo tribunal da capacidade institucional das agências reguladora para lidar com questões técnicas complexas é um fundamento autônomo relevante para uma postura deferente do TJRJ quanto ao resultado e à amplitude do controle?

O discurso de deferência específico foi adotado em um total de 16 das decisões judiciais pesquisadas. Em relação ao resultado, todas essas demandas tiveram um resultado favorável à AGENERSA $(100 \%)$. No que concerne à amplitude, 12 processos tiveram um controle puramente formal sobre a atuação da agência reguladora estadual (75\%).

A relevância de um discurso específico de deferência deve ser aferida a partir de sua comparação com os números relativos ao discurso genérico de deferência. É necessário examinar, pois, se uma prática autocontida similar em relação a resultado e amplitude do controle se verifica nos casos em que o discurso de deferência se baseia apenas em fundamentos como separação de poderes e/ou a impossibilidade de controle do mérito administrativo.

A presença de um discurso de deferência genérico é identificada num total de 56 decisões judiciais de $2^{\underline{a}}$ instância no TJRJ. Em relação ao resultado, apenas 1 processo levou à revisão judicial de um ato administrativo praticado à AGENERSA, com ampla deferência do tribunal $(98,21 \%)$. Já em relação à amplitude, há um total de 40 processos 


\section{A TEORIA DA DEFERÊNCIA E A PRÁTICA JUDICIAL: UM ESTUDO EMPÍRICO SOBRE O CONTROLE DO TJRJ À AGENERSA}

em que o controle do TJRJ recaiu apenas sobre a forma e o procedimento, sem qualquer juízo sobre os aspectos substantivos da decisão final da AGENERSA no curso dos procedimentos administrativos (71,43\%).

Estes resultados sugerem que a adoção explícita de um discurso de deferência específico não é determinante para uma postura autocontida em relação ao resultado e à amplitude de controle. Mesmo quando o tribunal adota discurso de deferência genérico, os resultados e a amplitude do seu controle tendem a revelar uma postura semelhantemente deferencial. Os índices percentuais de cada um dos casos apresentam variações inferiores a cinco portos percentuais, de modo que a mera presença de um discurso de deferência, seja ele específico ou genérico, já parece representar per se uma tendência de um resultado favorável à AGENERSA e de uma amplitude reduzida de controle, sem que a especificação deste discurso apresente impactos adicionais significativos.

\subsection{A relação entre a amplitude do controle e o seu resultado final}

A terceira questão que se enfrenta examina a relação entre a aplicação de um controle substantivo da decisão administrativa (deferência pela amplitude) e o maior índice de revisão judicial (deferência pelo resultado). Para tanto, é necessário comparar os casos catalogados como de controle amplo (substantivo) com aqueles classificados como de controle pouco amplo (meramente formal).

Quanto aos primeiros, do universo de 51 casos em que foi realizada análise material pelo TJRJ, apenas 8 decisões levaram à anulação ou à suspensão do ato praticado pela AGENERSA (15,69\%). 43 deles, por sua vez, tiveram como resultado a manutenção da decisão da agência (84,31\%). Na Apelação Cível nº 0030431-58.2013.8.19.0001, por exemplo, o Desembargador Relator Cherubin Helcias Schwartz Júnior concluiu que a multa aplicada pela agência reguladora foi demasiadamente alta, desvirtuando o caráter punitivo e educativo do poder sancionador. Em razão disso, confirmou a sentença de $1^{a}$ instância que reduziu o valor da multa à $10 \%$ do que havia sido inicialmente fixado pela entidade reguladora (RIO DE JANEIRO, 2016a). A penalidade também foi reduzida - dessa vez em $20 \%$ do seu valor original - na Apelação Cível no 0430482-38.2012.8.19.0001, em caso envolvendo a demora na instalação de gás de um usuário do serviço público (RIO DE JANEIRO, 2016e).

No Agravo de Instrumento n⿳0 0015141-50.2006.8.19.0000, por sua vez, o TJRJ suspendeu diversas previsões de deliberações AGENERSA do ano de 2016 que versavam sobre o momento correto em que os aumentos do preço do gás aplicados pela Petrobrás poderiam ser repassados aos consumidores pela concessionária (RIO DE JANEIRO, 2007). Trata-se de uma das duas demandas que não trata sobre a aplicação de penalidades, mas sim sobre um fator de extrema relevância para o equilíbrio 


\section{REVISTA ESTUDOS INSTITUCIONAIS}

JULHO/DEZEMBRO - ISSN 2447-5467

econômico-financeiro dos contratos de concessão (a revisão tarifária), no qual o TJRJ se substituiu ao regulador em uma decisão de efeitos prospectivos em todo o setor regulado.

Pois bem. Já quanto aos 82 casos em que o TJRJ controlou apenas aspectos formais das decisões da AGENERSA, 77 levaram à manutenção da decisão da agência (93,9\%), enquanto 5 levaram à revisão (cautelar ou definitiva) do entendimento firmado pela autoridade administrativa (6,1\%) - como, por exemplo, no Processo no 0014929-89.2007.8.19.0001, em que a multa foi anulada por ausência de intimação no processo

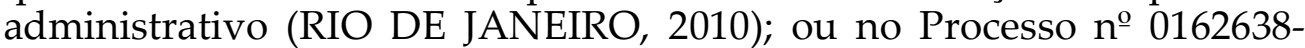
21.2013.8.19.0001, em que a multa foi anulada por ausência de motivação (RIO DE JANEIRO, 2016c).

Isso demonstra, por um lado, uma inclinação do TJRJ em concordar com aspectos substantivos das decisões tomadas pela AGENERSA no âmbito de seus processos administrativos. Por outro prisma, é possível afirmar a existência de uma leve tendência de maior revisão judicial quando a amplitude de controle é superior (isto é, substantiva).

\subsection{Os magistrados são mais deferentes em decisões de cognição sumária?}

A última questão a ser enfrentada é se as decisões proferidas em sede de cognição sumária apresentam um maior índice de deferência do que aquelas proferidas no bojo de apelações cíveis. Em tese, seria de se esperar um maior índice de decisões judiciais favoráveis à Administração Pública em decisões liminares (ante a já mencionada presunção de legitimidade dos atos administrativos). Afinal, decisões proferidas em sede de cognição exauriente podem conduzir a uma maior margem de controle, tendo que vista que, neste momento processual, as partes já puderam contraditar as teses jurídicas e defende-las por meios de provas, quando assim permitido.

Os dados relativos a este tópico foram apresentados no decorrer dos subitens anteriores. $\mathrm{O}$ objetivo deste subitem é, portanto, compará-los para que sejam extraídas possíveis tendências. Quanto a isso, registre-se que há um maior índice de deferência nas decisões de cognição sumária apenas em relação ao discurso (68,57\% versus $48,48 \%)$ e à amplitude de controle $(71,43 \%$ versus $56,57 \%)$. Em ambos os casos, as diferenças percentuais parecem significativas e indicam uma inclinação do tribunal a uma postura autorrestritiva quanto ao discurso e à amplitude de controle. Já no caso do parâmetro da deferência pelo resultado, a variação é de pequena monta em favor dos casos de cognição exauriente $(91,84 \%$ versus $87,5 \%)$. 


\section{CONCLUSÕES}

Este artigo tem origem em pesquisa desenvolvida por alunos da Escola de Direito do Rio de Janeiro da Fundação Getúlio Vargas durante o segundo semestre do ano de 2017. O objetivo central do trabalho foi verificar, empiricamente, o nível de deferência do TJRJ às decisões proferidas pela AGENERSA. Foram selecionados 134 processos com decisões relevantes para os fins da pesquisa, dentre os quais 99 tiveram decisões de $2^{\underline{a}}$ instância proferidas no curso de apelações cíveis (cognição exauriente) e 35 no bojo de agravos de instrumento (cognição sumária). $\mathrm{O}$ contencioso do TJRJ em relação à AGENERSA é composto, quase exclusivamente, por ações ajuizadas pela Companhia Distribuidora de Gás do Rio de Janeiro - CEG (133 de 134), quase todas elas tendo por objeto penalidades aplicadas no âmbito de processos administrativos sancionadores (132 de 134). Como afirmado ao longo deste artigo, a natureza sancionatória da grande maioria das decisões regulatórias judicializadas pode sugerir alguma cautela sobre as conclusões a propósito da existência ou não de uma postura autocontida do Judiciário fluminense em relação à generalidade de medidas administrativas. É que os dados apresentados ao longo do trabalho não necessariamente apontam tendências para outros tipos de atuação da AGENERSA, tal como a produção normativa ou a prolação de decisões em pleitos de reequilíbrio econômico-financeiro dos contratos de concessão.

A deferência judicial às agências reguladoras é um fenômeno de difícil identificação. Trata-se de um processo complexo e multifacetado que, muitas vezes, requer a avaliação de diversas variáveis para que se possam identificar seus indícios. Neste trabalho, foram adotados três parâmetros distintos para identificação do nível de deferência do TJRJ à AGENERSA: (i) a deferência pelo discurso; (ii) a deferência pelo resultado; e (iii) a deferência pela amplitude de controle.

A partir dos dados extraídos pelo estudo, foi possível apontar que o TJRJ (i) apresenta um discurso de deferência em pouco mais da metade de seus julgados em relação à AGENERSA (52,24\%); (ii) possui um índice baixo de revisão judicial dos atos da AGENERSA (9,77\%); e (iii) exerce controle de pouca amplitude, limitando o seu exame na maior parte das vezes a aspectos formais e procedimentais da atuação da agência reguladora estadual $(60,45 \%)$. A avaliação independente de tais variáveis sugere uma orientação deferente do tribunal fluminense em relação à autoridade administrativa. Mas a análise conjunta delas pode indicar, ainda, outras tendências do TJRJ.

Em primeiro lugar, foi analisado o impacto da adoção do discurso de deferência no resultado e na amplitude de controle. A partir dos dados levantados, foi possível verificar que a presença de um discurso de deferência leva a um percentual maior de manutenção de decisões da AGENERSA $(98,61 \%)$ do que nos casos em que o discurso é ausente 


\section{REVISTA ESTUDOS INSTITUCIONAIS}

JULHO/DEZEMBRO - ISSN 2447-5467

(80,33\%). O mesmo se diga em relação à amplitude de controle, no qual se constatou um maior percentual de decisões em que o controle se deu apenas sobre aspectos formais da atuação da AGENERSA quando o discurso de deferência é adotado como causa de decidir $(72,22 \%)$ do que quando não há discurso (48,39\%). Isso releva uma relação tendencial significativa entre discurso e postura do TJRJ - quando a primeira variável está presente, há uma maior propensão do tribunal a ser mais deferente na perspectiva do resultado e da amplitude do controle.

Em segundo lugar, a variação entre um discurso de deferência específico ou genérico é aparentemente irrelevante (ou tem impacto inconclusivo) para o resultado final do julgamento ou para a amplitude de controle, com percentuais de deferência pouco superiores no discurso específico. Independentemente do tipo adotado, a presença de um discurso de deferência como razão de decidir leva a resultados parecidos $(100 \%$ e $98,21 \%$ de índice de manutenção das decisões; e 75\% e 71,43\% de baixa amplitude de controle, respectivamente, nos discursos específicos e genéricos).

Em terceiro lugar, outro resultado interessante é o produto da conjugação dos fatores de deferência por amplitude e por resultado. Como demonstrado acima, mesmo quando o controle realizado pelo TJRJ é substantivo, a taxa de manutenção das decisões da AGENERSA é de $84,31 \%$. Já em relação ao controle formal, $93,9 \%$ dos casos levam a um resultado favorável à AGENERSA.

Em quarto e último lugar, registre-se que há um maior índice de deferência nas decisões de cognição sumária em comparação às decisões de cognição exauriente tanto em relação ao discurso $(68,57 \%$ versus $48,48 \%$ ) como em relação à amplitude de controle (71,43\% versus $56,57 \%$ ). Apenas a variável do resultado manutenção é mais presente nos casos de cognição exauriente $(91,84 \%$ versus $87,5 \%)$.

\section{REFERÊNCIAS}

ARAGÃO, Alexandre Santos de. Agências reguladoras e a evolução do direito administrativo econômico. Rio de Janeiro: Forense, 2002;

AZEVEDO, Paulo Furquim de; FERRAZ JUNIOR, Tércio Sampaio; MARANHÃO, Juliano Souza de Albuquerque. As inter-relações entre o processo administrativo e o judicial, sob a perspectiva da segurança jurídica do plano da concorrência econômica e da eficácia da 
A TEORIA DA DEFERÊNCIA E A PRÁTICA JUDICIAL: UM ESTUDO EMPÍRICO SOBRE O CONTROLE DO TJRJ À AGENERSA

regulação pública. São Paulo: USP, 2011. Relatório da pesquisa.

Disponível em: < https://bit.ly/2SpNZ7F>. Acesso em: 27 de out. de 2018.

BARNETT, Kent Harris; WALKER, Christopher Jay. "Chevron in the Circuit Courts". In: Michigan Law Review, Vol. 116, 2017, p. 01-73, 2017.

BINENBOJM, Gustavo. Uma Teoria do Direito Administrativo. 3. ed. Rio de Janeiro: Renovar. 2014.

CARVALHO FILHO, José dos Santos. Manual de direito administrativo. 31. ed. São Paulo: Atlas, 2017.

ESKRIDGE JR, William N.; BAER, Lauren E. The Continuum of Deference: Supreme Court Treatment of Agency Statutory Interpretations from Chevron to Hamdan. Geo. LJ, v. 96, p. 1083, 2007.

JORDÃO, Eduardo. Passado, Presente e Futuro: Ensaio sobre a História do Controle Judicial da Administração Pública no Brasil. In: WALD, Arnoldo; JUSTEN FILHO, Marçal; PEREIRA, Cesar Augusto Guimarães (Org.). O Direito Administrativo na Atualidade: Estudos em homenagem ao centenário de Hely Lopes Meirelles (1917-2017) Defensor do Estado de Direito. São Paulo: Malheiros, 2017.

. Controle judicial de uma Administração Pública complexa: a experiência estrangeira na adaptação da intensidade do controle. São Paulo: Malheiros, 2016;

; ROSE-ACKERMAN, Susan. Judicial review of executive policymaking in advanced democracies: beyond rights review. Admin. L. Rev., v. 66, p. 1, 2014.

; RIBEIRO, Maurício Portugal. Como desestruturar uma agência reguladora em passos simples. REI-REVISTA ESTUDOS

INSTITUCIONAIS, v. 3, n. 1, p. 180-209, 2017. 


\section{REVISTA ESTUDOS INSTITUCIONAIS}

JUSTEN FILHO, Marçal. Curso de Direito Administrativo. 5. ed. Belo Horizonte: Fórum, 2011.

KERR, Orin S. Shedding Light on Chevron: An Empirical Study of the Chevron Doctrine in the US Courts of Appeals. Yale J. on Reg., v. 15, p. 1, 1998.

KING, Jeff A. Institutional approaches to judicial restraint. Oxford Journal of Legal Studies, v. 28, n. 3, p. 409-441, 2008.

MAJONE, Giandomenico. Do Estado positivo ao Estado regulador: causas e consequências de mudanças no modo de governança. Revista do Serviço Público, v. 50, n. 1, p. 05-36, 2014.

MARANHÃO, Juliano Souza de Albuquerque. A revisão judicial de decisões de agências regulatórias: jurisdição exclusiva?. In: PRADO, Mariana Mota (Org.). O Judiciário e o Estado Regulador Brasileiro. São Paulo: FGV Direito SP, 2016, p. 26-46.

MOREIRA NETO, Diogo de Figueiredo. Curso de direito administrativo: parte introdutória, parte geral e parte especial. Rio de Janeiro: Ed. Forense, 2009.

MULLAN, David J. Recent developments in administrative law-The apparent triumph of deference. Canadian Journal of Administrative Law and Practice, v. 12, n. 2, 1998.

OLIVEIRA, Ana Claudia Beppu dos Santos. Regulação e Judiciário: considerações à luz da jurisprudência relativa às agências reguladoras estaduais. Revista de Direito Público da Economia - RDPE, Belo Horizonte, ano 8, n. 29, jan./mar., 2010. 


\section{A TEORIA DA DEFERÊNCIA E A PRÁTICA JUDICIAL: UM ESTUDO EMPÍRICO SOBRE O CONTROLE DO TJRJ À AGENERSA}

RIO DE JANEIRO. Tribunal de Justiça do Estado do Rio de Janeiro. Agravo de Instrumento (0002304-89.2008.8.19.0000). Relator: Paulo Mauricio Pereira, 18 de abril de 2009 (2009a). Disponível em: $<$ http://www1.tjrj.jus.br/gedcacheweb/default.aspx?UZIP=1\&GEDID=00 03937D6FB83DC0EB96453250219C16BC8A1693C3635F1E>. Acesso em: 31 out. 2018.

RIO DE JANEIRO. Tribunal de Justiça do Estado do Rio de Janeiro. Agravo de Instrumento (0015408-17.2009.8.19.0000). Relator: Cristina Tereza Gaulia, 28 de setembro de 2009 (2009b). Disponível em: <http://www1.tjrj.jus.br/gedcacheweb/default.aspx?UZIP=1\&GEDID=00 031D4A01D9DDFCF238C31676B0A04D81392DC402270E52>. Acesso em: 31 out. 2018.

RIO DE JANEIRO. Tribunal de Justiça do Estado do Rio de Janeiro. Agravo de Instrumento (0056600-51.2014.8.19.0000). Relator: Marcelo Lima Buhatem, 10 de março de 2015 (2015a). Disponível em: <http://www1.tjrj.jus.br/gedcacheweb/default.aspx?UZIP=1\&GEDID=00 04A8BE650A7578AC7EC499D334BD0C87E1C50359354E61>. Acesso em: 31 out. 2018.

RIO DE JANEIRO. Tribunal de Justiça do Estado do Rio de Janeiro. Agravo de Instrumento (0045368-42.2014.8.19.0000). Relator: Andre Emilio Ribeiro Von Melentovytch, 17 de abril de 2015 (2015b). Disponível em:

<http://www1.tjrj.jus.br/gedcacheweb/default.aspx?UZIP=1\&GEDID=00 04CBE3FF0AC8D0D15449D2CD4196A10377C5035D0D2247>. Acesso em: 31 out. 2018.

RIO DE JANEIRO. Tribunal de Justiça do Estado do Rio de Janeiro. Agravo de Instrumento (0010860-70.2014.8.19.0000). Relator: Paulo Mauricio Pereira, 23 de maio de 2014. Disponível em: $<$ http://www1.tjrj.jus.br/gedcacheweb/default.aspx?UZIP=1\&GEDID=00 04ACFEC47AFF184B0D328466AC4059F14AC5030F2D411E >. Acesso em: 31 out. 2018. 


\section{REVISTA ESTUDOS INSTITUCIONAIS}

RIO DE JANEIRO. Tribunal de Justiça do Estado do Rio de Janeiro. Agravo de Instrumento (0015141-50.2006.8.19.0000). Relator: Helda Lima Meireles, 24 de abril de 2007. Disponível em: $<$ http://www1.tjrj.jus.br/gedcacheweb/default.aspx?UZIP=1\&GEDID=00 0374613DAB7D89EFCCA4B332BB920C6D04DBC402040F3C >. Acesso em: 31 out. 2018.

RIO DE JANEIRO. Tribunal de Justiça do Estado do Rio de Janeiro. Agravo de Instrumento (0051790-72.2010.8.19.0000). Relator: Des. Inês da Trindade Chaves Melo, 14 de fevereiro de 2011. Disponível em: $<$ http://www1.tjr.jus.br/gedcacheweb/default.aspx?UZIP=1\&GEDID $=00$ 03C3EA4DFB93DF14C36191E58766BEA0D02AC4025D0906\&USER $=>$.

Acesso em: 31 out. 2018.

RIO DE JANEIRO. Tribunal de Justiça do Estado do Rio de Janeiro. Apelação (0014929-89.2007.8.19.0001). Relator: Ernani Klausner, 18 de fevereiro de 2010.2 Disponível em: $<$ http://www1.tjr.jus.br/gedcacheweb/default.aspx?UZIP=1\&GEDID=00 03EE76CF0B11FBDF0E239D4F90BB6452F8A4C402366119>. Acesso em: 31 out. 2018.

RIO DE JANEIRO. Tribunal de Justiça do Estado do Rio de Janeiro. Apelação (0030431-58.2013.8.19.0001). Relator: Cherubin Helcias Schwartz Júnior, 05 de maio de 2016 (2016a). Disponível em: $<$ http://www1.tjr.jus.br/gedcacheweb/default.aspx?UZIP=1\&GEDID=00 0495B0744072EF647B703E62915822DF1EC50506110618>. Acesso em: 31 out. 2018.

RIO DE JANEIRO. Tribunal de Justiça do Estado do Rio de Janeiro. Apelação (0134262-54.2015.8.19.0001). Relator: Benedicto Ultra Abicair, 25 de julho de 2016 (2016b). Disponível em: $<$ http://www1.tjrj.jus.br/gedcacheweb/default.aspx?UZIP=1\&GEDID $=00$ 041DCEB0CA1F438911291F299AE1465DF5C5052607121F >. Acesso em: 31 out. 2018. 


\section{A TEORIA DA DEFERÊNCIA E A PRÁTICA JUDICIAL: UM ESTUDO EMPÍRICO SOBRE O CONTROLE DO TJRJ À AGENERSA}

RIO DE JANEIRO. Tribunal de Justiça do Estado do Rio de Janeiro. Apelação (0158503-92.2015.8.19.0001). Relator: Custódio de Barros Tostes, 17 de agosto de 2017 (2017a). Disponível em: $<$ http://www1.tjr.jus.br/gedcacheweb/default.aspx?UZIP=1\&GEDID=00 04B3C036D58E51EC708C99F858F72C8502C50656501D61>. Acesso em: 31 out. 2018 .

RIO DE JANEIRO. Tribunal de Justiça do Estado do Rio de Janeiro. Apelação (0158579-53.2014.8.19.0001). Relator: Peterson Barroso Simão, 26 de setembro de 2017 (2017b). Disponível em: $<$ http://www1.tjrj.jus.br/gedcacheweb/default.aspx?UZIP=1\&GEDID=00 04423A84BFBCD4EBF2DC021D9F9D579FF5C5071C4A1F41>. Acesso em: 31 out. 2018.

RIO DE JANEIRO. Tribunal de Justiça do Estado do Rio de Janeiro. Apelação (0162638-21.2013.8.19.0001). Relator: Celso Luiz de Matos Peres, 20 de junho de 2016 (2016c). Disponível em: $<$ http://www1.tjrj.jus.br/gedcacheweb/default.aspx?UZIP=1\&GEDID=00 0476C6A6A4229C34284AB7885518D716B6C5051658440E >. Acesso em: 31 out. 2018.

RIO DE JANEIRO. Tribunal de Justiça do Estado do Rio de Janeiro. Apelação (0239612-65.2014.8.19.0001). Relator: Sirley Abreu Biondi, 16 de novembro 2016 (2016d). Disponível em: $<$ http://www1.tjrj.jus.br/gedcacheweb/default.aspx?UZIP=1\&GEDID=00 0430658C08809E4F37B2D36ECBF9E308C3C5054E284A25>. Acesso em: 31 out. 2018.

RIO DE JANEIRO. Tribunal de Justiça do Estado do Rio de Janeiro. Apelação (0364944-08.2015.8.19.0001). Relator: Cláudio Luiz Braga Dell'orto, 30 de março de 2017 (2017c). Disponível em: $<$ http://www1.tjrj.jus.br/gedcacheweb/default.aspx?UZIP=1\&GEDID=00 041409BB0754A774C329A57B214DEE553AC50617642F4E>. Acesso em: 31 out. 2018. 


\section{REVISTA ESTUDOS INSTITUCIONAIS}

RIO DE JANEIRO. Tribunal de Justiça do Estado do Rio de Janeiro. Apelação (0430482-38.2012.8.19.0001). Relator: Claudio Brandão de Oliveira, 05 de setembro de 2016 (2016e). Disponível em: $<$ http://www1.tjrj.jus.br/gedcacheweb/default.aspx?UZIP=1\&GEDID=00 045F877FF9D4FEEEF29E769385A15B45CEC50532583E4B >. Acesso em: 31 out. 2018.

RIO DE JANEIRO. Tribunal de Justiça do Estado do Rio de Janeiro. Apelação (0473492-35.2012.8.19.0001). Relator: Carlos Santos de Oliveira, 30 de julho de 2015 (2015c). Disponível em:

$<$ http://www1.tjrj.jus.br/gedcacheweb/default.aspx?UZIP=1\&GEDID=00 040993C709DE346F7442C9DE5127DF2EE9C50416420A45 >. Acesso em: 31 out. 2018.

SCHUCK, Peter H.; ELLIOTT, E. Donald. To the Chevron station: An empirical study of federal administrative law. Duke Lj, p. 984, 1990.

SOUZA, Suiá Fernandes de Azevedo; RIBEIRO, Yasmin Arbex. Breves notas sobre agências reguladoras municipais. Revista Brasileira de Direito Municipal - RBDM, Belo Horizonte, ano 14, n. 50, out./dez. 2013.

SUNSTEIN, Cass R. Law and Administration after

"Chevron". Columbia Law Review, v. 90, n. 8, p. 2071-2120, 1990.

VERÍSSIMO, Marcos Paulo. "Juízes deferentes?". Revista Brasileira de Estudos Constitucionais - RBEC,

Belo Horizonte, ano 6, n. 22, abr./jun. 2012.

WALINE, Jean. Droit Administratif. Paris: Dalloz, 2010.

WANG, Daniel Wei Liang; PALMA, Juliana Bonacorsi de; COLOMBO, Daniel Gama e. Revisão judicial dos atos das agências reguladoras: uma análise de jurisprudência brasileira. In: SCHAPIRO, Mario Gomes (org.). 
A TEORIA DA DEFERÊNCIA E A PRÁTICA JUDICIAL: UM ESTUDO EMPÍRICO SOBRE O CONTROLE DO TJRJ À AGENERSA

Direito Econômico Regulatório. São Paulo: FGV, 2010, versão digital, p. 236-305. 